\title{
医療機器の審査·安全に関わる学会の役割, 市販後安全の立場から \\ Roles of the academic society about the examination and the safety of medical devices from the aspect of Post Marketing Surveillance
}

\author{
○石井健介 \\ (独) 医薬品医療機器総合機構 安全部 \\ OKensuke Ishii
}

Medical Device Safety Division, Pharmaceuticals and Medical Devices Agency

\begin{abstract}
1. はじめに
医療技術の進歩に伴い, 特に医療機器は益々高度化·複雑化 してきており, それらを取り扱う使用者側にも高度なレベルが要求 される時代である. それは「医療機器=もの」が「使用者＝人」の 技量や習熟度により, その効果を大きく左右するためである. しか し, 医師一人が熟練していても, 施設の管理体制や医療機器の 保守・点検が不十分であれば，その効果を十分発揮できないだ けでなく、重大な事故につながる場合もある. 今後, 産・官・学共 通認識のもと, デバイス・ラグの解消や次世代医療機器の導入に 向けた様々な政策によって, 審査の迅速化が図られ, 新規性の 高い革新的な医療機器が市場導入された際の市販後安全対策 のあり方は, 重要な課題と考える.
\end{abstract}

\section{2. 医療機器による医療事故等の要因}

ここ数年，医療事故がマスコミ等でクローズアップされ，新聞紙 面やTVで医療機関の長らが深く頭を下げる光景を目にする. そ の中には慣れない医療機器を操作した結果によるものも少なくな い.このような背景もうけ, 平成 19 年度には改正医療法等が施行 され，医療機関における医療安全対策の充実のために医療機器 安全管理責任者の配置やその業務の明確化などが図られてきて いるところである.

完全な製造販売側の責任である品質不良を除けば, 医療機器 による医療事故の中には, 操作に関連したヒューマンエラー的な ものもある. また高度に複雑化した医療機器がその誘因の一つと 言われることもあるが, これは臨床研究の中でエビデンスが構築 され, 検証されてきた機能や性能でもあり, 一概に医療機器のみ が責められるものではなく, 臨床現場側と共同して再発防止に向 け解決すべき問題が含まれることがある.

\section{3. より優れた医療機器の迅速な提供に向けた政策}

現在, より優れた医療機器をより早く患者に届けるために, 革 新的な医療機器開発を促進し, 研究開発加実用化・普及に向 けて, また欧米で使用されながらも日本では未承認の医療機器, いわゆるデバイス・ラグの解消に向けて, 現在, 産・官・学等が一 体となり, 国の政策として取り組まれているところである. そのいく つかを挙げてみる.

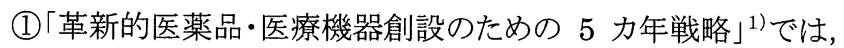
医療機器に関する事項として革新的な医療機器の評価指標の策 定・国際共同治験の推進・審査基準の策定等による審査の迅速 化や治験の円滑化などがあげられている.

(2)「医療技術産業戦略コンソーシアム (METIS)」 」2)では, 医学の みならずバイオテクノロジー, 情報技術等をも含めた幅広い科学・ 理工学分野全般を包含し, 異種産業も含めた産・官・学の連携に よって革新的な医療機器の実用化に向けての検討が進められて いる.

(3)「次世代医療機器評価指標検討会」3)では, 医療ニーズが高く 実用可能性の高い次世代医療機器の分野について, 効率的な 開発及び迅速な審査が行えるよう, 開発段階から承認審査を見
通した審査にかかる評価指標を作成し，公表することを目的とし， 前述した革新的な医療機器の評価指標が作成されつつある. (4)「医療ニーズの高い医療機器等の早期導入に関する検討会」 4)では, 欧米で使用されながらも日本では未承認の医療機器, い わゆるニーズの高い医療機器について, 学会の要望を踏まえな がら既存のデータを活用した申請等により, 優先的に承認審査を 実施する試みが始まっている.

\section{4. 早期㝰入による市販後安全面での課題}

しかし, 革新的な医療機器などが迅速に国内市場に導入され た際の安全性の検証やモニタリング手法など, 市販後安全対策 の仕組みをどのように講じ, 国民の安全を確保していくかなどの 議論は,これらの政策の中にはあまり見当たらない.

審査の迅速化などが図られた場合, 医薬品同様, 医療機器に おいても市販後の安全対策の重要性が一層増加する. 産・官・学 の連携により生み出された医療機器については, 同じく産・官・学 の連携のもと市販後のフォローアップを含めたデータベースを構 築し, そのアウトカムを社会に発信するとともに, 問題点を科学的 に早期に明らかにできる市販後調查体制の必要性が高い.

しかし,一般的にこのような市販後のレジストリーの構築には, コストや医師自身のインセンティブ, 患者のフォローアップの困難 さなどの問題を抱えるが, 欧米での市販後のデータと比較可能な 国内の市販後データが存在しない場合には, 引き続き市販後の 安全性に関する情報については, 欧米の結果を参考にせざるを 得ないといらジレンマがある.

\section{5. 最後に}

医療機器の進歩が患者の生命予後に大いに貢献していること は言うまでもない. 限られた治験からより広範囲の集団に使用さ れた市販後に果たしてその医療機器が同様の性能を安全に発揮 するか, 新技術のリスクを市販後に正確に評価する仕組みは, 患 者へのベネフィットを最大限にするものであり, また次の世代の機 器への改良や応用にも寄与できるものと考える.

市販後安全の仕組みに学会の協力は不可欠であり, 今まさに 市販後の科学的な評価体制の確立に向け, 産・官・学が連携す る時ではないかと思う.

\section{6. 参考文献}

1) 革新的医薬品・医療機器創設のための 5 力年戦略 (平成 20 年 5 月 23 日一部改定版) http://www8.cao.go.jp/cstp/project/bt2/haihu2/sanko1 2.pdf

2) 医療技術産業戦略コンソーシアム(METIS) http://www.jfmda.gr.jp/metis/index.html

3) 次世代医療機器評価指標検討会 http://www.mhlw.go.jp/

4) 医療ニーズの高い医療機器等の早期導入に関する検討会 http://www.mhlw.go.jp/ 